\title{
Impact of Library User Education Program on Undergraduate Students in Benue State University, Makurdi, Nigeria
}

\author{
Gbuushi, Joseph Ahemba, CLN (B.Sc. Lib. (BSU), MLS) \\ University Library and Information Services Benue State University, \\ Makurdi Benue State, Nigeria \\ Ubwa, Theophilus Terwase, CLN (B.Sc. Lib. (BSU), MLS) \\ Library and Information Science Benue State University, \\ Makurdi Benue State, Nigeria
}

Doi: 10.19044/esj.2018.v14n7p126 URL:http://dx.doi.org/10.19044/esj.2018.v14n7p126

\begin{abstract}
The study sought to examine the impact of user education on the utilization of library resources by undergraduate students of Benue State University, Makurdi. The study adopted the survey research design and the population consisted of 25,232 regular undergraduate students in 7 faculties which a sample size of 380 respondents were selected using proportional random sampling technique. Self-developed questionnaires were distributed among sample undergraduate students. However, only three hundred and forty one $341(89.73 \%)$ questionnaires were returned in good shape and analyzed using frequency distribution, percentage and mean. The findings of the study revealed that user education positively impacted the undergraduate students' use of library resources and the academic performance. The method employed in teaching user education includes lecture method, independent assignment, and practical exercises among others. The study identified some problems that includes; over population, lack of instructional materials, poor monitoring of staff, inadequate qualified staff, limited time allocation, inadequate accommodation and space. The strategies that can be adopted to enhance effective user education to undergraduate students as indicated in the findings includes; provision of adequate staff, proper ventilation and illumination of venue, regular monitoring and control of user education procedures, adjustment of user education time to suit students, positive attitude of staff to the program among others. The study concludes that the library occupies a central place in the achievement of educational objectives of the students and this has made user education indispensable in the library.
\end{abstract}


Keywords: User education, utilization of library resources, undergraduate students, Benue State University, Makurdi

\section{Introduction}

Universities are often referred to as the citadel of learning and represent the apex institution for the acquisition of knowledge. Based on this perception, Ifidon (1998) holds that universities are established for four related purposes of teaching, learning, and research and community/public service. The university library is indispensable in the actualization of all four, as none of them can effectively take place in the absence of a functional library. That is, the university library supports the teaching, learning and research needs of the institution they serve. The responsibility of academic libraries is to ensure that the use of its information resources and services are maximized to benefit its users, hence the need for library user education program which is also in line with the National University Commission which encourage university libraries in other to equip students with the effective use of library materials (NUC, 2007).

User education refers to the process of making library patrons learn how to make effective and efficient use of the library system through the acquaintance of skills in identification, location, search, retrieval and use of information resources. It encompasses all activities undertaken to help the undergraduate student become efficient users of information. These include library instruction, library orientation, bibliographic instruction and information literacy.

According to Uwakwe et al (2016), user education is a process whereby potential users to the library are made to learn how to make efficient and effective use of the library and its resources through the acquisition of knowledge and skills in identification, location, retrieval and exploitation of information. User education can be in the form of orientation/training programmes, workshop, and seminar; "know your library programs" occasionally organized by the library for both new and old library users. These programs/activities may be packaged in hard copy that is manuals, handout or in soft copies that is compact discs. The fundamental objective of user education is to expose, acquaint and inculcate in the clients, the basic knowledge of understanding and skills which are necessary for effective and efficient use of the library resources and services. User education is, therefore, all about empowering undergraduate students with knowledge and skills to enable them to make judicious use of information resources and services available in a given library.

The adoption and implementation of technological devices obviously place on library service provider the responsibility of carrying library use along through design/packaging of quality user education determines the rate 
of use of nay library and also actualizes the sustainable optimal user satisfaction. The corollary to this is that a poorly packaged user education may account for low rate of use of library resources and services, which equally runs counter to the user satisfaction policy of the library.

Ossai (2011) found that most students use information resources for their academic workload which includes information to complete assignments and test and research; they also utilize information resources to satisfy their personal developments, health, implementation and global information. According to Baro, Onyenania and Oni (2010) the internet is the most utilized information sources by students followed by lecturers' notes, handouts and the library.

\section{Statement of the Problem}

With the explosion of information on daily basis, the users need sufficient knowledge and ability to navigate and select relevant information library user education programs are necessary for all users especially the fresh men, because it involves instruction on how to access and use information resources available in the library. User education can help users developed the necessary skills for research and lifelong learning and to make maximum use of library resources available to them. This study seeks to investigate the impact of library user education on the utilization of library resources by undergraduate students in Benue State University, Makurdi. The following research questions were formulated to guide the study:

1. What is the impact of user education program on undergraduate student's utilization of library resources in Benue State University, Makurdi?

2. What are the methods employed in teaching undergraduate students user education program in Benue State University, Makurdi?

3. What are the problems that hinder effective library user education program to undergraduate students in Benue State University, Makurdi?

4. What are the strategies can be adopted to enhance effective user education to undergraduate students in Benue State University, Makurdi?

\section{Literature Review}

Considering the impact of user education on users, Vasanthi (2001) stated that, the aim of user education is to widen the use of the varying library resources which will enable lecturers to improve their teaching and research while the students learn more in order to achieve better results in their work. In a similar vein, Olaniyan (2007) state that user education acquaints students with the most useful reference works, books, periodicals and their field of study. It impacts on them how to use the card catalogue, indexes, teaches them the proper form and rules for making a scientific bibliography, teaches them how to prepare a scientific or technical report. 
Discussing on various methods of imparting or teaching the skills on the use of library, Maduako (2013) explained that, methods of teaching user education consist of all types of activities designed to teach user about library facilities, services, organizations, resources and search strategies in order to equip with basic skills to enable them to make optimal, effective, efficient and independent use of information resources and services available in the library. Uhegbu (2007) categorized user education teaching method into two namely: orientation- where professional librarians teach users various aspects of the library as well as acquaint them with penalties for any offence committed in the library; library tour which involves talking users aware of what the library has in terms of new acquisitions, new service, new rules or conditions governing library use. Aina (2004) asserted that library tour could be one-toone session- where the librarian explains the activities that go on in the different sections of the library without necessary destructing the staff of the various sections or classroom instruction. During the session, documents of interest, location of shelves holding books on subject of interest and arrangement of books on shelves etc.

It is well acknowledged fact that library user education is necessary prior to effective library use. However, there are a number of problems that hinder the smooth operation of the program in university libraries. One of the major problems encountered in the execution of library instruction program is lack of library services at all level of education. For instance, Nna-Etuk (2003) traces the problems of user education in Nigeria to the unavailability of real library services at all levels of education especially earlier stages. This lack of solid base according to him is evident at various schools whose literature indicates the absence of libraries, reading materials and qualified staff to provide library services. Similarly, Joseph (2005) identifies the following problems of user education: overdependence on one day orientation program, lack of collective curriculum for user education program in Nigeria Universities; use of unqualified personnel to teach the course. Edom (2007) itemizes the problems as factors: inadequate time, large number of students, inadequate number of instructors/lecturers, inadequate facilities/equipment, the attitude of lecturers, attitudes of students, and use of library combined with use of English.

To solve the problems of user education, Joseph (2005) asserts on the need for explicit statements of objectives, availability of infrastructure, qualified trainers, careful choice of teaching methods and regular systematic evaluation. Akimbola (2007) on the significance of user education recommends that the user education program in our tertiary institutions should be overhauled to make it more standard. Adequate qualified personnel should be recruited to undertake the teaching of the course effectively; the course 
should be allocated reasonable time on the time table so as to enable practical aspects taught effectively.

Akimbola (2007) remedying the problems user education recommended the time schedule for the teaching of the course should be reviewed to when most of the students must have arrived the campus irrespective of some unforeseen circumstances. Practical lectures should also be organized at the university library to further enhance the students' use of catalogue and other library resources. He further states that all the library rules and regulations should be documented and a copy of such issued to all the students to further acquaint them with some of the rules that were not mentioned during the use of library lectures.

In the opinion of Ajibero (1998), when service techniques and information storage formats become complex, users will surely require some assistance by way of user-education program. Organized user-education he argues sharpens the appetite of the users to avail themselves of the facilities in the library. Unfortunately, though many academic staff and students are incapable of retrieving information from the library on their own without assistance. It is therefore, highly necessary that university libraries should have a user education unit for the purpose of training users in the full exploration of library services and resources. He goes further to argue that it has become fashionable and practical to go beyond oral instructions and to publish or pint manuals or brochures that describe library resources and their users explaining that these resources can be exploited for the benefit of users. These should always be a laid down procedure of alerting users about new and other sources of information by the user education unit

\section{Methodology}

This study is a descriptive survey. The population is undergraduate students of Benue State University, Makurdi, which has 25,282 undergraduate students in 7 Faculties. About 379 undergraduate students were selected using the Krejcie and Morgan formula. Information was gathered using a questionnaire of 36 open-ended questions. Data analysis includes descriptive statistics, frequency and percentage and Mean.

\section{Data Analysis}

A total of 380 questionnaires were distributed among sample undergraduate students but $341(89.73 \%)$ questionnaires were returned in good shape. Respondents were $55 \%$ female and $45 \%$ male (table 1 )

\begin{tabular}{|c|c|c|}
\hline Gender & Number & $\%$ \\
\hline Female & 188 & 55 \\
\hline Male & 153 & 45 \\
\hline Total & 341 & 100 \\
\hline
\end{tabular}


About $27 \%$ of the student were 100 level, $22 \%$ were 200 level, $28 \%$ were 300 level, $19 \%$ were 400 level and $4 \% 500$ level undergraduate students in various faculties.

Figure 1. Frequency distribution of undergraduate students according to level of education

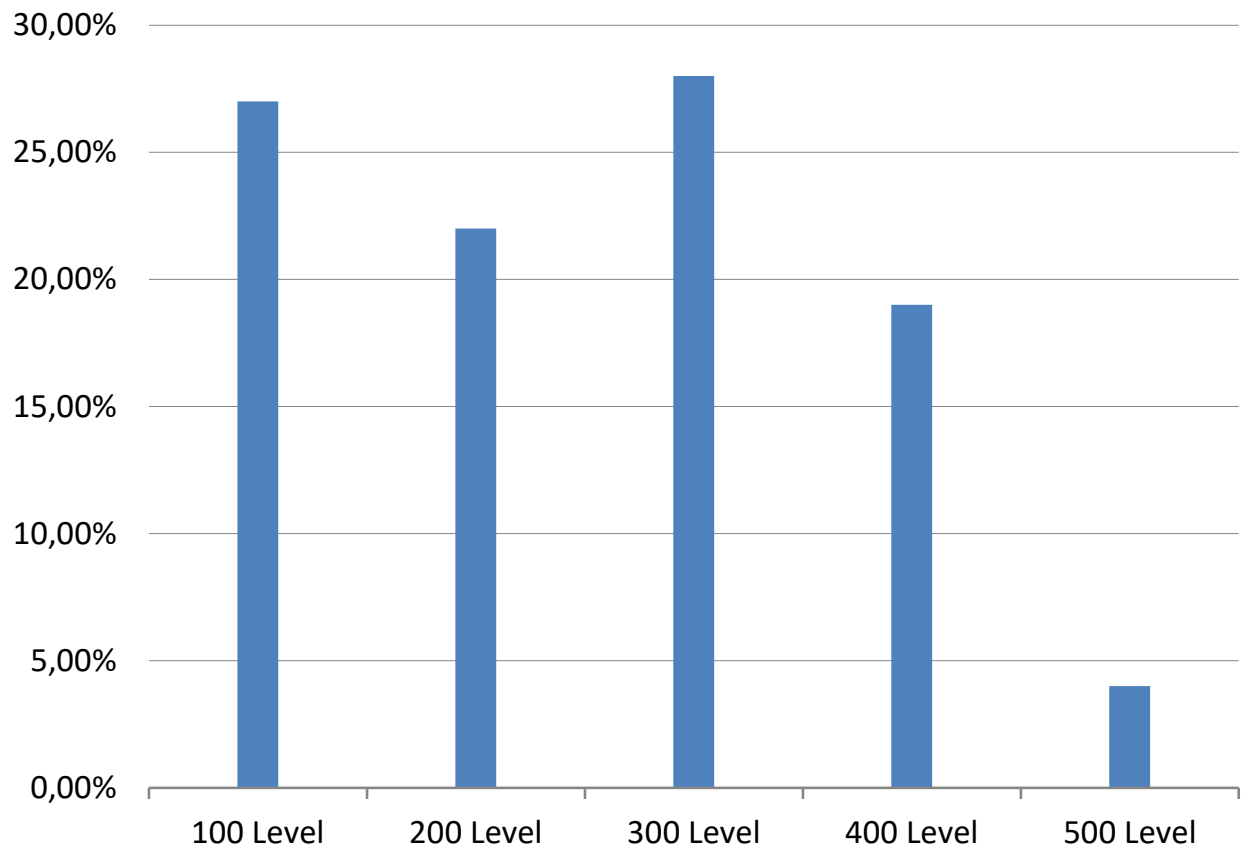

Research Question 1: What is the impact of user education program on undergraduate student's utilization of library resources in Benue State University, Makurdi?

Table 2: Impact of user education program on undergraduate student's utilization of library

\begin{tabular}{|c|c|c|c|c|c|c|}
\hline \multicolumn{7}{|c|}{ resources } \\
\hline Impact of user education & SA & A & UD & $\mathrm{D}$ & SD & Mean \\
\hline $\begin{array}{l}\text { I acquire skills for } \\
\text { independent learning }\end{array}$ & $\begin{array}{l}279 \\
82 \%\end{array}$ & $\begin{array}{c}45 \\
13 \%\end{array}$ & $\begin{array}{c}6 \\
2 \%\end{array}$ & $\begin{array}{l}- \\
-\end{array}$ & $\begin{array}{c}11 \\
3 \%\end{array}$ & 4.71 \\
\hline $\begin{array}{l}\text { It enhance my capacity to } \\
\text { carry out research }\end{array}$ & $\begin{array}{c}198 \\
58 \%\end{array}$ & $\begin{array}{c}114 \\
33 \%\end{array}$ & - & $\begin{array}{c}12 \\
4 \%\end{array}$ & $\begin{array}{c}17 \\
5 \%\end{array}$ & 4.36 \\
\hline $\begin{array}{l}\text { It has enlightened me on the } \\
\text { various structures of literature } \\
\text { in my field and related field or } \\
\text { areas }\end{array}$ & $\begin{array}{l}126 \\
37 \%\end{array}$ & $\begin{array}{l}200 \\
59 \%\end{array}$ & $\begin{array}{c}4 \\
1 \%\end{array}$ & $\begin{array}{l}11 \\
3 \%\end{array}$ & $\begin{array}{l}- \\
-\end{array}$ & 4.29 \\
\hline $\begin{array}{l}\text { It has enhanced my use of } \\
\text { index as a retrieval tool }\end{array}$ & $\begin{array}{l}168 \\
49 \%\end{array}$ & $\begin{array}{l}114 \\
33 \%\end{array}$ & $\begin{array}{l}- \\
-\end{array}$ & $\begin{array}{c}57 \\
17 \%\end{array}$ & $\begin{array}{c}2 \\
1 \% \\
\end{array}$ & 4.14 \\
\hline $\begin{array}{c}\text { It made me aware of the value } \\
\text { of the library in academic } \\
\text { pursuit }\end{array}$ & $\begin{array}{c}69 \\
20 \%\end{array}$ & $\begin{array}{l}228 \\
67 \%\end{array}$ & $\begin{array}{l}- \\
-\end{array}$ & $\begin{array}{c}44 \\
13 \%\end{array}$ & $\begin{array}{l}- \\
-\end{array}$ & 3.94 \\
\hline $\begin{array}{l}\text { I acquire skills to cite } \\
\text { references and documents for } \\
\text { my research work }\end{array}$ & $\begin{array}{c}87 \\
26 \%\end{array}$ & $\begin{array}{l}171 \\
50 \%\end{array}$ & $\begin{array}{l}- \\
-\end{array}$ & $\begin{array}{c}83 \\
24 \%\end{array}$ & $\begin{array}{l}- \\
-\end{array}$ & 3.77 \\
\hline
\end{tabular}




\begin{tabular}{|c|c|c|c|c|c|c|}
\hline $\begin{array}{c}\text { It exposed me to the } \\
\text { bibliographic database of the } \\
\text { library }\end{array}$ & $\begin{array}{r}126 \\
37 \%\end{array}$ & $\begin{array}{c}105 \\
31 \%\end{array}$ & $\begin{array}{c}2 \\
1 \%\end{array}$ & $\begin{array}{c}39 \\
11 \%\end{array}$ & $\begin{array}{c}69 \\
20 \%\end{array}$ & 3.53 \\
\hline $\begin{array}{l}\text { It has greatly improved my } \\
\text { ability to retrieve needed } \\
\text { information from the library }\end{array}$ & $\begin{array}{c}66 \\
19 \%\end{array}$ & $\begin{array}{c}172 \\
50 \%\end{array}$ & $\begin{array}{c}2 \\
1 \%\end{array}$ & $\begin{array}{c}57 \\
17 \%\end{array}$ & $\begin{array}{c}44 \\
13 \%\end{array}$ & 3.45 \\
\hline $\begin{array}{c}\text { It made me aware of the scope } \\
\text { of library resources }\end{array}$ & $\begin{array}{r}114 \\
33 \% \\
\end{array}$ & $\begin{array}{c}85 \\
25 \% \\
\end{array}$ & - & $\begin{array}{c}45 \\
13 \% \\
\end{array}$ & $\begin{array}{c}99 \\
29 \% \\
\end{array}$ & 3.22 \\
\hline $\begin{array}{c}\text { I can use the catalogue } \\
\text { effectively to retrieve } \\
\text { information }\end{array}$ & $\begin{array}{l}103 \\
30 \%\end{array}$ & $\begin{array}{c}48 \\
14 \%\end{array}$ & $\begin{array}{l}- \\
-\end{array}$ & $\begin{array}{l}125 \\
37 \%\end{array}$ & $\begin{array}{c}65 \\
19 \%\end{array}$ & 3.00 \\
\hline $\begin{array}{l}\text { It has increased my } \\
\text { motivation to use the library }\end{array}$ & $\begin{array}{c}79 \\
23 \% \\
\end{array}$ & $\begin{array}{c}34 \\
10 \% \\
\end{array}$ & $\begin{array}{r}29 \\
9 \% \\
\end{array}$ & $\begin{array}{r}165 \\
48 \% \\
\end{array}$ & $\begin{array}{c}34 \\
10 \% \\
\end{array}$ & 2.88 \\
\hline It develops my reading culture & $\begin{array}{c}57 \\
17 \% \\
\end{array}$ & $\begin{array}{c}51 \\
15 \% \\
\end{array}$ & $\begin{array}{c}5 \\
2 \% \\
\end{array}$ & $\begin{array}{c}114 \\
33 \% \\
\end{array}$ & $\begin{array}{r}114 \\
33 \% \\
\end{array}$ & 2.48 \\
\hline $\begin{array}{l}\text { It inculcate in me the ability } \\
\text { to think critically }\end{array}$ & $\begin{array}{c}62 \\
18 \% \\
\end{array}$ & $\begin{array}{c}46 \\
13 \% \\
\end{array}$ & $\begin{array}{c}6 \\
2 \% \\
\end{array}$ & $\begin{array}{r}125 \\
37 \% \\
\end{array}$ & $\begin{array}{r}102 \\
30 \% \\
\end{array}$ & 2.39 \\
\hline
\end{tabular}

The analysis on Table 2 reflects the respondents' opinion on the impact of user education on their use of the library. All the items on the table recorded a high response score with mean of $>2.5$. This indicates that the course user education has positively impacted the students. The implication of this finding is that undergraduate students in BSU can effectively and efficiently use their library resources.

\section{Research Question 2: What are the methods employed in teaching undergraduate students user education program in Benue State University, Makurdi?}

Table 3: Methods employed in teaching undergraduate students user education program in Benue State University, Makurdi

\begin{tabular}{|c|c|c|c|c|c|c|}
\hline Methods employed & SA & A & UD & D & SD & Mean \\
\hline Lecture & 171 & 125 & 2 & 38 & 5 & 4.60 \\
& $50 \%$ & $37 \%$ & $1 \%$ & $11 \%$ & $1 \%$ & \\
\hline Library orientation & 228 & 57 & 2 & 41 & 15 & 4.32 \\
& $67 \%$ & $17 \%$ & $1 \%$ & $12 \%$ & $4 \%$ & \\
\hline Independent assignments & 160 & 125 & - & 43 & 13 & 4.10 \\
& $47 \%$ & $37 \%$ & - & $13 \%$ & $4 \%$ & \\
\hline Demonstration method & 114 & 162 & 2 & 12 & 51 & 3.81 \\
& $33 \%$ & $48 \%$ & $1 \%$ & $4 \%$ & $15 \%$ & \\
\hline Practical exercise & 159 & 67 & 4 & 69 & 42 & 3.68 \\
& $47 \%$ & $20 \%$ & $1 \%$ & $20 \%$ & $12 \%$ & \\
\hline Library tour & 12 & 40 & 5 & 159 & 125 & 1.99 \\
& $4 \%$ & $12 \%$ & $1 \%$ & $47 \%$ & $37 \%$ & \\
\hline
\end{tabular}

Table 3 above shows that high mean are recorded with lecture method or teaching and less with other items. This indicates that the students are taught mainly through the lecture method and library orientation and independent assignments with mean score of 4.60, 4.32 and 4.1 respectively. 


\section{Research Question 3: What are the problems that hinder effective library user education program to undergraduate students in Benue State University, Makurdi?}

Table 4: Problems that hinder effective library user education program to undergraduate students in Benue State University, Makurdi

\begin{tabular}{|c|c|c|c|c|c|c|}
\hline Problems & SA & A & UD & D & SD & Mean \\
\hline Over population & 298 & 31 & - & 12 & - & 4.80 \\
& $87 \%$ & $9 \%$ & - & $4 \%$ & - & \\
\hline Lack of instructional & 293 & 38 & - & 8 & 2 & 4.79 \\
materials & $86 \%$ & $11 \%$ & - & $2 \%$ & $1 \%$ & \\
\hline Inadequate qualified staff & 125 & 103 & 4 & 41 & 68 & 4.79 \\
& $37 \%$ & $30 \%$ & $1 \%$ & $12 \%$ & $20 \%$ & \\
\hline Students negative attitude to & 64 & 271 & - & 6 & - & 4.75 \\
the program & $19 \%$ & $79 \%$ & - & $2 \%$ & - & \\
\hline Limited time allocation & 280 & 46 & - & 12 & 3 & 4.72 \\
& $82 \%$ & $13 \%$ & - & $4 \%$ & $1 \%$ & \\
\hline Unconducive environment & 273 & 50 & 3 & 7 & 8 & 4.71 \\
& $80 \%$ & $15 \%$ & $1 \%$ & $2 \%$ & $2 \%$ & \\
\hline Inadequate learning & 267 & 57 & 3 & 6 & 8 & 4.67 \\
facilities & $78 \%$ & $17 \%$ & $1 \%$ & $2 \%$ & $3 \%$ & \\
\hline Inadequate & 277 & 36 & 2 & 19 & 7 & 4.63 \\
accommodation/space & $81 \%$ & $11 \%$ & $1 \%$ & $6 \%$ & $2 \%$ & \\
\hline Poor attendance by students & 273 & 35 & 2 & 12 & 19 & 4.56 \\
& $80 \%$ & $10 \%$ & $1 \%$ & $4 \%$ & $6 \%$ & \\
\hline Unsuitable lecture periods & 250 & 65 & - & 6 & 17 & 4.51 \\
& $73 \%$ & $19 \%$ & - & $3 \%$ & $5 \%$ & \\
\hline Few staff teaching the & 231 & 62 & - & 31 & 17 & 4.14 \\
program & $68 \%$ & $18 \%$ & - & $9 \%$ & $5 \%$ & \\
\hline Attitude of staff to the & 48 & 230 & - & 57 & 6 & 3.75 \\
course & $14 \%$ & $67 \%$ & - & $17 \%$ & $2 \%$ & \\
\hline Poor monitoring of staff & 78 & 35 & 35 & 40 & 153 & 2.55 \\
& $23 \%$ & $10 \%$ & $10 \%$ & $12 \%$ & $45 \%$ & \\
\hline & & & & & & \\
\hline
\end{tabular}

Table 6 shows respondents opinion on the problems hindering effective user education to undergraduate students in Benue State University, Makurdi. Almost all the items in table 6 recorded a high mean, over population $($ mean $=4.80)$, lack of instructional materials $($ mean $=4.79)$, inadequate and qualified staff (mean=4.79) among others. The result of the analysis reveals that all the items on table 6 are problems hindering effective library user education program to undergraduate students in Benue State University, Makurdi. 


\section{Research Question 4: What are the strategies can be adopted to enhance effective user education to undergraduate students in Benue State University, Makurdi?}

Table 7: Strategies that can be adopted to enhance effective user education to undergraduate students in Benue State University, Makurdi

\begin{tabular}{|c|c|c|c|c|c|c|}
\hline Strategies & SA & $\mathrm{A}$ & UD & $\mathrm{D}$ & SD & Mean \\
\hline Provision of adequate staff & $\begin{array}{l}311 \\
91 \% \\
\end{array}$ & $\begin{array}{r}18 \\
5 \% \\
\end{array}$ & - & $\begin{array}{c}12 \\
4 \% \\
\end{array}$ & - & 4.88 \\
\hline $\begin{array}{l}\text { Proper ventilation and illumination of } \\
\text { venue }\end{array}$ & $\begin{array}{l}301 \\
88 \%\end{array}$ & $\begin{array}{r}18 \\
5 \% \\
\end{array}$ & - & $\begin{array}{c}10 \\
3 \% \\
\end{array}$ & $\begin{array}{l}12 \\
4 \% \\
\end{array}$ & 4.78 \\
\hline $\begin{array}{l}\text { Regular monitoring and control of user } \\
\text { education procedures }\end{array}$ & $\begin{array}{l}307 \\
90 \%\end{array}$ & $\begin{array}{c}6 \\
2 \% \\
\end{array}$ & - & $\begin{array}{l}13 \\
4 \% \\
\end{array}$ & $\begin{array}{l}15 \\
4 \%\end{array}$ & 4.69 \\
\hline $\begin{array}{l}\text { Adjustment of user education time to } \\
\text { suit students }\end{array}$ & $\begin{array}{l}296 \\
87 \% \\
\end{array}$ & $\begin{array}{r}18 \\
5 \% \\
\end{array}$ & $\begin{array}{c}4 \\
1 \% \\
\end{array}$ & $\begin{array}{c}6 \\
2 \% \\
\end{array}$ & $\begin{array}{r}17 \\
5 \% \\
\end{array}$ & 4.67 \\
\hline $\begin{array}{l}\text { Provision of handbill/print outs during } \\
\text { user education session }\end{array}$ & $\begin{array}{l}285 \\
84 \%\end{array}$ & $\begin{array}{c}31 \\
9 \% \\
\end{array}$ & $\begin{array}{l}- \\
-\end{array}$ & $\begin{array}{c}14 \\
4 \%\end{array}$ & $\begin{array}{c}11 \\
3 \% \\
\end{array}$ & 4.66 \\
\hline Provision of computers & $\begin{array}{r}291 \\
85 \% \\
\end{array}$ & $\begin{array}{r}16 \\
5 \% \\
\end{array}$ & - & $\begin{array}{c}25 \\
7 \% \\
\end{array}$ & $\begin{array}{r}10 \\
3 \% \\
\end{array}$ & 4.63 \\
\hline $\begin{array}{l}\text { Payment of enhance honorarium to } \\
\text { facilitators } \\
\end{array}$ & $\begin{array}{l}283 \\
83 \%\end{array}$ & $\begin{array}{r}30 \\
9 \% \\
\end{array}$ & - & $\begin{array}{c}13 \\
4 \% \\
\end{array}$ & $\begin{array}{l}15 \\
4 \% \\
\end{array}$ & 4.62 \\
\hline $\begin{array}{l}\text { Expansion of user education } \\
\text { programmes }\end{array}$ & $\begin{array}{l}279 \\
81 \%\end{array}$ & $\begin{array}{l}23 \\
7 \%\end{array}$ & $\begin{array}{c}3 \\
1 \% \\
\end{array}$ & $\begin{array}{c}18 \\
5 \%\end{array}$ & $\begin{array}{c}18 \\
5 \%\end{array}$ & 4.55 \\
\hline Provision of public address system & $\begin{array}{c}258 \\
76 \% \\
\end{array}$ & $\begin{array}{c}38 \\
11 \% \\
\end{array}$ & - & $\begin{array}{c}31 \\
9 \% \\
\end{array}$ & $\begin{array}{c}14 \\
4 \%\end{array}$ & 4.45 \\
\hline $\begin{array}{l}\text { Workshops/seminars on capacity } \\
\text { building of staff }\end{array}$ & $\begin{array}{r}114 \\
33 \% \\
\end{array}$ & $\begin{array}{c}81 \\
24 \% \\
\end{array}$ & $\begin{array}{l}20 \\
6 \% \\
\end{array}$ & $\begin{array}{c}86 \\
25 \% \\
\end{array}$ & $\begin{array}{c}40 \\
12 \% \\
\end{array}$ & 3.42 \\
\hline $\begin{array}{l}\text { Increase time should be allocated to the } \\
\text { teaching of user education }\end{array}$ & $\begin{array}{l}217 \\
64 \% \\
\end{array}$ & $\begin{array}{c}86 \\
25 \% \\
\end{array}$ & $\begin{array}{c}4 \\
1 \% \\
\end{array}$ & $\begin{array}{r}28 \\
8 \% \\
\end{array}$ & $\begin{array}{c}6 \\
2 \% \\
\end{array}$ & 4.41 \\
\hline Positive attitude of students & $\begin{array}{l}216 \\
63 \% \\
\end{array}$ & $\begin{array}{c}86 \\
25 \% \\
\end{array}$ & $\begin{array}{c}4 \\
1 \% \\
\end{array}$ & $\begin{array}{r}29 \\
9 \% \\
\end{array}$ & $\begin{array}{c}6 \\
2 \% \\
\end{array}$ & 4.40 \\
\hline Training and retraining of staff & $\begin{array}{l}220 \\
65 \%\end{array}$ & $\begin{array}{c}80 \\
23 \%\end{array}$ & - & $\begin{array}{l}27 \\
8 \%\end{array}$ & $\begin{array}{l}13 \\
4 \%\end{array}$ & 4.36 \\
\hline $\begin{array}{c}\text { Provision of enough instructional } \\
\text { materials }\end{array}$ & $\begin{array}{l}201 \\
59 \%\end{array}$ & $\begin{array}{c}92 \\
27 \%\end{array}$ & - & $\begin{array}{l}30 \\
9 \% \\
\end{array}$ & $\begin{array}{c}18 \\
5 \%\end{array}$ & 4.26 \\
\hline Provision of adequate staff/facilitators & $\begin{array}{r}109 \\
32 \%\end{array}$ & $\begin{array}{c}86 \\
25 \% \\
\end{array}$ & $\begin{array}{c}3 \\
1 \% \\
\end{array}$ & $\begin{array}{c}92 \\
27 \% \\
\end{array}$ & $\begin{array}{c}51 \\
15 \% \\
\end{array}$ & 3.32 \\
\hline Positive attitude of staff to the program & $\begin{array}{c}86 \\
25 \%\end{array}$ & $\begin{array}{c}81 \\
24 \%\end{array}$ & $\begin{array}{c}4 \\
1 \% \\
\end{array}$ & $\begin{array}{r}113 \\
33 \% \\
\end{array}$ & $\begin{array}{c}57 \\
17 \% \\
\end{array}$ & 3.08 \\
\hline
\end{tabular}

The analysis in table 7 above shows that almost all the respondents representing mean $>3.08$ and above indicates that the items above will help overcome problems that hinder effective library user education to undergraduate students in Benue State University, Makurdi.

\section{Discussion of Findings}

From the data presentation, analysis and interpretation, the findings of the study could be summarized thus:

The students understand the concept of user education. This implies that they know what they stand to gain from the course. This understanding will help them to be serious with the program and attend lectures regularly. 
Their understanding of the concept of user education is in line with Maduoko (2013) who defined user education as a planned process and technique that is aimed at equipping library users with the basic skills to help make optimal use of the resources available in their library. It is any effort or program which guide and instruct existing and potential users individually or collectively with objective of futility the recognition of their information needs, effective and efficient use of information services and the assessment of those services.

The impact of user education on undergraduate student's utilization of library resources, the students indicated that it greatly improved their ability to retrieve needed information; they can use the catalogue effectively to retrieve information, made them aware of the scope of the library among others. This is in line with Vasanthi (2001) who states that the aim of user education is to widen the use of the varying library resources which will enable students to learn more in order to achieve better results in their work and research.

The library user education therefore has a positive impact on the quality of student's education as there is a significant relationship between library user education and students grades. That is, effective and efficient use of the library and its resources is the bedrock of academic excellence.

On the methods employed in teaching the undergraduate students user education; lecture method was indicated as mostly used, independent assignment, practical exercises among others. This however, indicated more than two methods of teaching user education unlike Uhegbu (2007) who categorized user education teaching methods into two namely; orientationwhere programmed librarians teach users various aspects of the library as well as acquaint them with penalties for any offence committed in the library; library tour which involves talking users aware of what the library has in terms of new acquisition, new services, new rules and conditions governing library users. These various methods help the students to understand the activities, aims and objectives of the library.

The study also finds that the problems that hinder effective library use education relates to undergraduate students includes; over population, lack of instructional materials, poor monitoring of staff, inadequate qualified staff, limited time allocation, inadequate accommodation and space among others. The findings are line with Edom (2007) itemizes the problems as factors: inadequate time, large number of students, inadequate number of instructors/lecturers, inadequate facilities/equipment, the attitude of lecturers, attitudes of students, and use of library combined with use of English.

The strategies that can be adopted to enhance effective user education to undergraduate students as indicated in the findings includes; provision of adequate staff, proper ventilation and illumination of venue, regular monitoring and control of user education procedures, adjustment of user education time to suit students, positive attitude of staff to the program among 
others. In support of this finding, Edom (2007) observed that timing of the program, quality of course delivery; one finding of the program is some of the areas that affect the program which must be recognized. In agreement, Edom and Lawal (1996) contributing to improved user education program in Nigerian university libraries identified lack of personnel, lack of professionals for teaching and practical work. Despite the fact that it is well acknowledged that library user education is necessary prior to effective library use, these problems hinder the smooth operation of the program in the library.

Therefore, to solve the problems of user education, there is every need to explicit statements of objectives, availability of infrastructure, qualified trainers, careful choice of teaching methods and regular systematic evaluation.

\section{Conclusion}

The library has been described as the life wire and the pivot of academic activities within the university system. It role in teaching and learning process cannot be overstressed. For optimum utilization of the library and its resources, user education program was introduced. The major objective is to inculcate user basic knowledge and skills to make effective use of the library resources. This study dwelt on the impact of user education on the utilization of library resources by undergraduate students in Benue State University, Makurdi. The study found that:

1. User education program has positively updated the undergraduate students' use of the library as well as their academic performance.

2. The methods adopted in teaching of the programmes includes, library tour, lecture method, demonstration method and library orientation.

3. The problems that militate against effective user education includes; over population, lack of instructional materials, inadequate and unqualified staff, limited time allocation to the program, unconducive library environment, inadequate space among others.

4. To remedy these problems, the following recommendations are proffered; adequate and qualified librarians should be employed to teach user education program, this will help the problem of over population.

When there is enough and qualified instructors to handle the course, the number of students assigned to a particular teacher will reduce. This will create room for adequate monitor of students as well as guarantee quality teaching and learning of the course.

The time allocated to the teaching of the course should be relevant. More time should be allocated to the course and the scheduling should be made to connect to students. Also, conducive and enabling environment should be made available for the teaching of the program. This calls for provision of more and larger spaces to accommodate the students. The facilities and the environment of the classroom should be made conducive for learning. 
Instructional materials such as public address system and projectors should be made available. This will help to make the course interesting and stimulate interest towards the course.

\section{Recommendations} made:

Based on the findings of this study, the following recommendations are 1. There should be a detailed course outline for user education. This is against the present situation of sketchy mention of use of library in NUC general studies scheme. This can be done by developing a well-articulated scheme of work based on National University Commission (NUC), Minimum Academic Structure (MAS). The scheme should include lectures and practical sessions in libraries to complement the theoretical aspect of it.

2. University authorities should provide venues that are conducive for teaching user education. The venues should have enough seats, tables, adequate ventilation, illumination and functional public address system.

3. User education programs should no longer dwell largely on traditional library practices but should include lectures in the area of information literacy and information technology. This will further expose undergraduate students on how to use computerized libraries and internet facilities which are very vital in everyday living today

\section{References:}

1. Aina, L. O. (2004). Library and information science test for Africa. Ibadan: Third World Information Services Limited. Pp. 21-25

2. Ajibero, M. I. (1998). User expectation of Nigerian University Library Services in the $21^{\text {st }}$ Century in ed Salisu, T.R and Olanloku, S. O Committee of University librarians of Nigeria Universities (CULNU): Proceedings of the Ibadan and Ekpoma Seminar 1992 and 1994, 8299.

3. Akimbola, O. O. (2001-7). Significance of User education program on the use of library. International Journal of Research in Education 4(1\&2): 188-192.

4. Baro, E. E., Onyenania, G. O. \& Oni O. (2010). Information seeking behaviour of undergraduate students in the humanities in three universities in Nigeria. South African Journal of Libraries and Information Science 76(2)

5. Edom, U. S. \& Lawal, O. O. (1996). Towards improving user education program in Nigerian University library. African Journal of Library, Archival and Information science, 6(1): 31-36 
6. Edom, B. O. (2007). The Impact of user education on the university libraries in Nigeria. Heartland Journal of library and information services 1(1): 43-48

7. Ifidon, B. I. (1998). The Challenges and functionalities of developing research collections in Nigerian University libraries. Gateway Library Journal 1(2): 63

8. Joseph, M. (2005). Encouraging user education in Nigerian academic libraries towards effectiveness. Journal of research in education 2(1\&2): 24-30

9. Maduako, P. U. (2013). User education and library use in colleges of education in Abia and Imo states. Library Philosophy and Practice (ejournal). 955.http://digitalcommons.unl.edu/libphilprac/955

10. Nna-Etuk, G. M. (2003). The Concept of user education: the role of stakeholders in Nigerian universities. African Journal of Education and information Management, 5(1): 89-99

11. National Universities Commission (2007). Benchmark Minimum Academic Standards for Undergraduate Programmes in Nigerian Universities, [Online]. Available at: http://www.nuc.edu.ng/nucsite/File/DASS/BMAS\%20SOCIAL\%20S CIENCE.pdf

12. Olaniyan, B. F. (2007). Instruction in the use of library in the university of Lagos. Nigerian Libraries 2(1 \& 2): 123.

13. Ossai, N. B. (2011). How law students utilize information resources: A case study of the University of Benin City. International journal of library and information science 3 (1): 1-14.

14. Uhegbu, A. N. (2007). The Information User: Issues and themes. Okigwe: Whytem prints

15. Uwakwe, S. B., Oyeneke, C. O. \& Njoku, I. N. (2016). Effect of User education on law students use of the library: A case study of the faculty of law library, Imo State University, Owerri, Nigeria. Journal of information and knowledge management, 7 (1): 70-85

16. Vasanthi, M. C. (2001). The Challenging environment of academic libraries. End user education and planning strategies for libraries in India. Library philosophy and practice. 4:1 